Jurnal Professional FIS UNIVED Vol.5 No.2 Desember 2018

\title{
PENYELESAIAN MASALAH PERTANAHAN MELALUI MEKANISME MEDIASI OLEH OMBUDSMAN REPUBLIK INDONESIA PERWAKILAN PROVINSI BENGKULU
}

Oleh:

\author{
RAJI REZA ILAHI, TITIEK KARTIKA, ALIMANSYAH \\ Program Studi Administrasi Publik FISIP Universitas Bengkulu
}

\begin{abstract}
Resolving the problem of land maladministration by the Ombudsman of the Republic of Indonesia through a mediation mechanism is a very important method for both reporting parties and the reported party to find the best solution that benefits both parties. This study aims to find out how the process of problem solving through a mediation mechanism by the Ombudsman of the Republic of Indonesia Representative of Bengkulu Province. This study uses descriptive qualitative methods with informant retrieval techniques, namely purposive sampling. The informants in this study were the Chief Representative; Head of Report Inspection and Verification, Head of Report Inspection Division, Member of Report Inspection and Verification, Member of Report Examination, Secretariat of Ombudsman of Republic of Indonesia Representative of Bengkulu Province and 2 Reporting Persons / General Communities, using data collection techniques for Observation, Interview and Documentation. The results of this study are the process of resolving the land problem through a mediation mechanism carried out by the Ombudsman of the Republic of Indonesia Bengkulu Representative through 3 processes, namely the process of summoning the reporter and the reporter, the Communication Process in Mediation and the Solution produced in the mediation. a case of maladministration using the mediation method, and a solution from the reporting party and the reported party that has been agreed upon in the mediation is completed with the minutes as a result of the mediation on the joint decision.
\end{abstract}

Keywords: settlement, mediation mechanism, ombudsman of the Republic of Indonesia representative of Bengkulu Province

\section{PENDAHULUAN}

Peningkatan kualitas pelayanan publik sangatlah diperlukan setiap neraga, dalam meningkatkan kualitas pelayanan yang baik untuk masyarakat, dibalik pelayanan publik yang baik tersebut diperuntukan juga untuk perbaikan aparatur negara yang mempunyai sikap yang tidak terpuji, untuk menghindari dari berbagai macam tindakan KKN (korupsi, kolusi, nepotisme) yang ada didalam aparatur pemerintahan. Sesuai dengan yang dikemukanan oleh Max Weber, dalam pengertian Birokrasi adalah sebagai sebuah organisasi yang disusun atas dasar rasionalitas, bermakna pengorganisasian 
yang tertib, teratur dalam hubungan kerja yang berjenjang berdasarkan tata kerja atau prosedur kerja yang jelas, tetapi dalam keadaanya praktiknya, dalam menjalankan hubungan kerjasama dengan pemerintahan terkadang mendapatkan tindakan yang mengecewakan, seperti pelayanan yang berbelit-belit, terlalu lama, tidak adanya keterbukaan, serta biaya yang sangat mahal, tindakan seperti inilah yang saat ini sedang diatasi oleh pemerintahan Indonesia.

Ombudsman Republik Indonesia sebelumnya bernama Komisi Ombudsman Nasional adalah lembaga negara di Indonesia yang mempunyai kewenangan mengawasi penyelenggaraan pelayanan publik baik yang diselenggarakan oleh penyelenggara negara dan pemerintahan, Lembaga ini dibentuk berdasarkan UndangUndang Nomor 37 Tahun 2008 tentang Ombudsman Republik Indonesia yang disahkan dalam Rapat Paripurna DPR RI pada tanggal 9 September 2008. Upaya pembentukan lembaga Ombudsman di Indonesia oleh pemerintah dimulai ketika Presiden B.J. Habibie, kemudian dilanjutkan oleh penggantinya, yakni K.H. Abdurrahman Wahid. Pada bulan Maret Tahun 2000, K.H. Abdurrahman Wahid mengeluarkan Keputusan Presiden Nomor 44 Tahun 2000 tentang Komisi Ombudsman Nasional, sehingga mulai saat itu, Indonesia memasuki babak baru dalam sistem pengawasan Pembentukan lembaga Ombudsman di Indonesia.

Untuk lebih mengoptimalkan fungsi, tugas, dan wewenang komisi Ombudsman Nasional, Perlu dibentuk Undang-undang tentang Ombudsman Republik Indonesia sebagai landasan hukum yang lebih jelas dan kuat Akhirnya pada tanggal 7 Oktober 2008 ditetapkanlah Undang-Undang Republik Indonesia Nomor 37 Tahun 2008 Tentang Ombudsman Republik Indonesia. Adanya Ombudsman disetiap daerah perwakilan, sangat membantu masyarakat dalam meningkatkan dan pencegahan adanya maladministrasi di Indonesia, Provinsi Bengkulu sendiri sudah adanya perwakilan Ombudsman untuk Provinsi Bengkulu dalam mencegah maladministrasi, Ombudsman publik, dalam berbagai masalah masyarakat yang diselesaikan oleh Ombudsman perwakilan Bengkulu, Mulai dari laporan masyarakat, Pelayanan pendidikan, kesehatan dan pertanahan juga menjadi laporan masyarakat yang banyak diselesaikan oleh Ombudsman.

Penulis mengambil permasalahan pertanahan juga dikarenakna belum adanya penelitian mengenai kasus pertanahan seperti kita ketahui kasus pertanahan masi banyak terjadi pada masyarakat di daerah, sedangkan kasus tinggi lainnya kenapa penulis tidak mengambil penelitian mengenai bidang tersebut, sudah banyak nya peneliti mengambil penelitian di bidang tersebut, seperti pendidikan, kepegawaian, kesehatan dan kepolisian sudah banyaknya penelitian yang sudah di bidang tersebut. Didalam pengaduan masyarakat mengenai subtansi pertanahan yang dihadapi oleh masyarakat mengenai kasus pertanahan dibagi menjadi 3 (tiga) sebagai berikut: 1 . Sengketa Tanah 2. Konflik Tanah 3. Perkara Tanah Ombudsman pihak netral. Lewat Ombudsman masyarakat bisa lebih smooth dalam menyelesaikannya di luar proses pengadilan. Proses mediasi inilah akhirnya mungkin ada kesepakatan penyelesaian antara pelapor dan terlapor yang dilaporkan pada Ombudsman. Oleh karena itu penulis tertarik membahas mengenai kasus pertanahan karena memang sangat tepat untuk dibahas dan diteliti, Maka dari itu penulis meneliti tentang Proses penyelesian masalah pertanahan melalui mekanisme mediasi oleh Ombudsman Republik Indonesia Perwakilan Provinsi Bengkulu. 


\section{METODE PENELITIAN}

Penelitian ini dilakukan dengan menggunakan metode kualitatif deskriptif. Penelitian kualitatif menurut Sugiono dalam (Pasolong, 2016: 161) adalah metode penelitian yang digunakan untuk meneliti pada kondisi objek alamiah, sebagai lawannya adalah eksperimen, dimana peneliti adalah sebagai instrumen kunci, teknik pengumpulan data dilakukan secara trianggulasi.

Laporan Yang Terselesaikan dengan Metode Penyelesaian Oleh Ombudsman Republik Indonesia Perwakilan Provinsi Bengkulu.

\begin{tabular}{|c|c|c|c|c|}
\hline \multirow{2}{*}{ No } & \multirow{2}{*}{ Metode Penyelesaian } & \multicolumn{3}{|c|}{ Jumlah Laporan } \\
\hline & & 2015 & 2016 & 2017 \\
\hline 1 & Bukan Wewenang & 4 & 11 & 14 \\
\hline 2 & Investigasi Lapangan & 3 & 10 & 17 \\
\hline 3 & Kl carifikasi Lisan & 11 & 51 & 77 \\
\hline 4 & Klarifikasi Tertulis & 62 & 52 & 31 \\
\hline 5 & Mediasi/Konsiliasi & 3 & 4 & 4 \\
\hline 6 & Pelimpahan/Diteruskan & 6 & 2 & 1 \\
\hline 7 & Permintaan Pelapor & 12 & 7 & 18 \\
\hline 8 & Saran & 22 & 24 & 30 \\
\hline 9 & $\begin{array}{c}\text { Tidak Ditemukan } \\
\text { Maladministrasi }\end{array}$ & 3 & 5 & 14 \\
\hline 10 & Tidak Melengkapi Data & 1 & 8 & 9 \\
\hline & Jumlah & 127 & 174 & 215 \\
\hline
\end{tabular}

Sumber : Hasil Penelitian, 2018

Data di atas mengambarkan kondisi laporan masyarakat yang masuk di Ombudsman Republik Indonesia Perwakilan Provinsi Bengkulu, tentu dalam proses penyelesaian yang di hadapi Oleh Ombudsman Republik Indonesia Perwakilan Provinsi Bengkulu, Proses Mediasi menjadi proses yang cukup panjang.
HASIL PENELITIAN DAN

\section{PEMBAHASAN}

Proses Pemanggilan Pelapor dan Terlapor Dalam Melakukan Mediasi

Pemanggilan adalah cara/proses memanggil/mengajak kepada seseorang/kelompok untuk datang ke suatu acara/menghadiri kepada yang memanggil, hal ini seperti yang di dalam proses melakukan mediasi di Ombudsman Republik Indonesia, dimana pelapor ialah seseorang yang melaporkan atas tindakan kasus maladministrasi sedangkan terlapor instansi/kelompok yang di laporkan atas dugaan melakukan maladministrasi yang dilakukan pemanggilan oleh Ombudsman untuk melakukan proses mediasi. Dengan demikian, pentingnya untuk memahami proses pemanggilan ini secara tepat tentang berbagai aspek mediasi, Proses pemanggilan merupakan point pertama dalam melakukan proses mediasi dan juga tahapan awal dari melukan proses mediasi nantinya. Semua proses yang dilakukan dilaksanakan secara tertib dan di atur dalam undang-undang nomor 25 tahun 2009, Peraturan Ombudsman Republik Indonesia Nomor 26 Tahun 2017, dan Peraturan melakukan mediasi antara kedua bela pihak, Selanjutnya mengenai kasus No: 0196/LM/XI/2017/BKL ini, Ombudsman sedikit kesulitan dalam pemanggilan hingga meminta klarifikasi atas dugaan maladministrasi dalam kasus tersebut, di karenakan dari beberapa pihak terlapor/instansi pemerintahan setempat merasa ketakutan dan sedikit menghambat jalan kerja Ombudsman dalam pencarian data dilapangan" (Hasil wawancara, November 2018).

Hasil ini menyampaikan bahwa proses tersebut tidak begitu mempengaruhi dalam proses melakukan mediasi nantinya, dikarenakan dalam pemanggilan tersebut Ombudsman tersendiri mempunyai wewenang pemanggilan paksa kepada instansi terlapor apabila tidak mempenuhi 
pemanggilan Ombudsman tersebut, akan tetapi pemanggilan tersebut biasanya cukup lama di penuhi oleh pelapor dan terlapor dikarenakan untuk mencocokan melakukan proses mediasi tersebut diperlukan waktu yang tepat sesuai kesepakatan pelapor dan terlapor dan proses ini cukup memakan waktu lama, belum lagi tidak ada batasan waktu bagi Ombudsman untuk menentukan waktu tersebut, Sesuai kesepakatan dan kesiapan terlapor untuk menyiapkan bahanbahan yang di perlukan dalam proses mediasi nantinya.

\section{Pola Komunikasi Dalam Proses Mediasi}

Pola komunikasi sebagai bentuk atau pola hubungan dua orang atau lebih, dalam proses pengiriman dan penerimaan pesan dengan cara yang tepat sehingga pesan yang dimaksud dapat dipahami di dalam mediasi juga dalam penyampaian yang di sampaikan dari pelapor dan terlapor adalah pesan yang akan menjadi solusi dalam mediasi yang disimpulkan oleh mediator nantinya solusi tersebut dan disampaikan kembali kepada pihak yang dimediasi. Pola komunikasi dan model mediasi yang digunakan dalam proses mediasi di Ombudsman Republik Indonesia yang menjadi kunci sukses terjalannya proses mediasi tersebut pola komunikasi yang sering digunakan dalam mediasi ialah pola Komunikasi Multi arah. Peneliti mencari informasi dalam kasus No: 0196 / LM / XI / 2017 / BKL yang langsung menanyakan sekaligus mencari tahu bagaimana pola komunikasi dalam proses mediasi terkhususnya penyampaian dari pihak Ombudsman, Pelapor Huzaimah mengungkapkan bahwa:

"Saya sebenarnya sedikit kecewa karena saya tidak mendapatkan apa yang saya inginkan atas hak saya, karena dalam mediasi tersebut saya tidak mendapatkan apa yang sebenarnya menjadi hak saya, dikarenakan dalam hasil mediasi tersebut saya tidak dapat apa yang saya inginkan yaitu SKT karena dari pihak kelurahan yang menghambat menurut saya, akan tetapi saya sudah cukup mendapatkan penjelasan mengenai soal tanah tersebut dan kenapa pihak kelurahan tidak mau mengeluarkan SKT"

(Hasil Wawancara, November 2018).

Berdasarkan Kasus No: 0196 / LM / XI / 2017 / BKL pola komunikasi yang di sampaikan sudah cukup membantu terbukti adanya pernyataan dalam kasus diatas bahwasanya Ombudsman sudah berkomunikasi terhadap beberapa pihak dilapangan untuk menyelesaikan kasus tersebut, serta dalam pola komunikasi dalam proses mediasi tersebutpun Ombudsman masi berada pihak netral karena dalam kasus tersebut Ombudsman hanya sebagai fasilitator saja dan yang sering berbicara dalam mediasi tersebut adalah pelapor/terlapor. Jadi peran Ombudsman dalam mediasi tersebut hanyalah menfasilitasi dalam kasus tersebut seorang mediatorpun tidak banyak berbicara karena sudah ditemukan data data yang konkrit dilapangan.

\section{Solusi Yang Ditawarkan Dalam Proses Mediasi}

Solusi ialah enyelesaian/pemecahan masalah/jalan keluar, dalam mediasi solusi tersebut tidak selalu mencapai titik kesepakatan bersama dikarenakan harus adanya penekanan yang lebih dari seorang mediator yang dalam hal ini terus menerus yang akan jadi pusat perhatian dalam mediasi tersebut yang bertanggung jawab mencari solusi terbaik dalam permasalahan tersebut, merangkum dengan baik permasalahan hingga kebutuhan pada masing-masing pihak melakukan evaluasi terhadap solusi yang di tawarkan pada masing- masing pihak, serta memilih solusi yang di setujui oleh para pihak yang sedang berkonflik. Solusi yang ditawarkan dalam proses mediasi peran Ombudsman 
sebagai pihak yang mefasilitasi serta netral memberikan tawaran solusi hingga tercapainya kesepakatan dalam mediasi tersebut dan ditutup dalam berita acara mulai dari ringkasan terjadinya pelapor datang ke Ombudsman atas dugaan maladministrasi hingga terselesainya kasus tersebut. Solusi yang ditawarkan pada kasus No: 0196 / LM / XI / 2017 / BKL penyampaian langsung dari tim pemeriksa laporan yaitu $\mathrm{AB}$ mengatakan:

"Ombudsman sudah mencari solusi yang terbaik dan pemecahan masalah yang terbaik bagi kedua bela pihak, pelapor sudah menerangkan dan menjelaskan seperti apa konflik yang di alami pelapor terhadap masalah kasus dugaan maladministrasi yang dihadapi pelapor, dalam kasus tersebut pihak BPN dan kelurahan dan pihak lainya tidak dapat menjelaskan secara detail kepada pelapor kenapa tanah yang di miliki pelapor tidak dapat di SKT kan, dikarenakan tanah tersebut terletak dulunya merupakan rawarawa namun saat ini sudah ditimbun oleh pihak lain, yaitu, sebuah lingkungan yang menjadi bagian dari masyarakat sekitar. Maka dari itu, untuk permohonan tambahan, SKT yang pelapor ajukan tidak dapat dikeluarkan secara spekulan, yang dibutuhkan untuk biaya- biaya umum berupa jalan yang diperuntukkan bagi masyarakat sekitar tanah tersebut karena tertera pada peraturan karena dalam Pasal 13 Undang- Undang Republik Indonesia Nomor 2 Tahun 2012 Tentang Pengadaan Tanah Bagi Kepentingan Umum Kilat, Dalam laporan pelapor sampaikan bahwa tanah yang diajukan penyusunan SKT yang sudah dalam rencana proyek (termasuk dalam peta Sertipikat Hak Milik an. Rohani No: 01595), Lembaga ini tidak dapat lagi menerima SKT karena itu sudah menjadi fasilitas umum untuk kepentingan masyarakat sekitar, maka dari itu fungsi
Ombudsman dalma hal ini sebagai fasilitator hingga penyelesaian masalah tersebut sudah selesai dan menjelaskan kepada pihak pelapor mengenai tanah tersebut" (Hasil wawancara, November 2018).

Penyelesaian kasus yang dilaporkan di Ombudsman terkhususnya dalam sengketa pertanahan yang menggunakan metode mediasi/konsiliasi Ombudsman menutut hasil penyelesaian kasus tersebut melalui berita acara yang sudah kuat berdasarkan dasar hukum yang ada, dikarenakan melalui berita acara tersebut juga Ombudsman dapat mengontrol dan memberikan penekanan pada pihak pihak yang tidak mentaati kesepatan/tidaknya dalam mediasi tersebut. Jadi Peran Ombudsman memanglah hanya fasilitator saja dalam penyelesaian kasus maladministrasi yang ada terkhusnya penyelesaian kasus yang menggunakan metode mediasi.

\section{PENUTUP}

Setelah melalui tahap penelitian dan pembahasan dari hasil penelitian. Peneliti akan memberikan kesimpulan dari hasil penelitian dan memberikan saran, Berdasarkan rumusan masalah, bagaimana proses penyelesaian masalah pertanahan melalui mekanisme mediasi oleh Ombudsman Republik Indonesia Perwakilan Provinsi Bengkulu. Maka pada penelitian ini telah di temukan jawabannya. Sehingga kesimpulan dari skripsi ini mengungkapkan bagaimana proses penyelesaian masalah pertanahan melalui mekanisme mediasi oleh Ombudsman Republik Indonesia Perwakilan Provinsi Bengkulu adalah sebagai berikut :

1. Proses pemanggilan pelapor dan terlapor dalam melakukan mediasi.

2. Proses pemanggilan pelapor dan terlapor diawali dengan adanya laporan masalah kasus maladministrasi terlebih dahulu 
hingga baru terjadinya proses PVL dan adanya Pemeriksaan laporan sehingga sampai kedalam proses mediasi proses pemanggilan tersebut sedikit banyaknya memakan waktu yang cukup lama yang mengakibatkan kepada kerugian kepada pelapor dikarenakan harus menunggu kapan terjadinya mediasi, disini menunggu dikarenakna susahnya menentukan waktu untuk pertemuan Pola komunikasi dalam proses mediasi.

3. Pola Komunikasi dalam proses mediasi tersebut yang lebih aktif adalah pelapor dan terlapor, Ombudsman terbukti pada beberapa kasus di atas menjelaskan bahwa pihak Ombudsman hanya sebagai fasilitator untuk memediasikan dan segaligus mengawas nantinya diajalankan apa tidak tuntutan pelapor tersebut.

4. Solusi yang ditawarkan dalam proses mediasi ini ialah masi ditentukan dari pihak pelapor dan terlapor itu tersendiri bagaimana proses terbaiknya dikarena Ombudsman disini berperan hanya menjadi fasilitator yang akan memediasi kedua bela pihak jadi, Ombudsman republik indonesia tuangkan dalam berita acara yang harus di laksanakan dari pihak terlapor dan pelapor yang sudah di sepakati besama dalam proses mediasi tersebut.

\section{DAFTAR PUSTAKA}

Ahmadi, Rulam. 2014. Metodologi Penelitian Kualitatif. Yogyakarta, ArRuzz Media

Emzir. 2014. Metode Penelitian Kualitatif: Analisis Data. Jakarta, Rajawali Pres
Erick S. Holle. 2011. Pelayanan Publik Melalui Electronic Government : Upaya Meminimalisir Praktek Maladministrasi Dalam Meningkatan Public Service, Jurnal Sasi Vol.17 No.3.

Edi As'Adi. 2011. Hukum Proyek Konstruksi Bagunan Dalam Perspektif Pelayanan Publik Yang Baik Di Indonesia. Yogyakarta, Graha Ilmu

Hidayat, Irsan. 2011. Efektivitas Lembaga Ombudsman Republik Indonesia (Study Kasus: Analisis Hasil Kerja Ombudsman Berdasarkan Laporan Tahun 2009- 2010), Bengkulu, Perpustakaan Dekanat Fisip. Skripsi

Idrus, Muhammad. 2009. Metode Penelitian Ilmu Sosial. Jakarta, Erlangga

Masthuri, Budi. 2005. Mengenal Ombudsman Indonesia. Jakarta, Pradnya Paramita

Nawawi, Hadari dan Hadari Martini. 1995. Instrumen Penelitian Bidang Sosial. Yogyakarta, Gajah Mada University Press

Pasalong, Harbani. 2016. Metode Penelitian Administrasi Publik. Bandung, Alfabeta

Sudaryono. 2017. Metodologi Penelitian. Jakarta, Rajawali Pers

Sugiyono. 2014. Metode Penelitian Kuantitatif, Kualitatif, Dan $R \& D$. Bandung, Alfabeta

Yulianti, Henny. 2016. Analisis Kerja Ombudsman Republik Indonesia Perwakilan Provinsi Bengkulu Dalam Substansi Pengaduan Bidang Kesehatan, B e n g kulu, Perpustakaan Dekanat Fisip. Skripsi 